\title{
Assessment of the state of Lake Maloe Lebyazhye (Kazan, Russia), based on zooplankton, for the purpose of eco-rehabilitation
}

\author{
Nazlygul A. Urazaeva, Olga Yu. Derevenskaya
}

Department of Environmental Engineering and Water Resources Managment, Institute of Management, Economics and Finance, Kazan Federal University, 18 Kremlyovskaya Street, Kazan 420008, Russian Federation, Russia

Abstract

Aim: The work is devoted to the study of zooplankton community structure of Lake Maloe Lebyazhye (Kazan, Russia). Previously, Lake Lebyazhye consisted of 4 lakes, connected by ducts. Over the past decades, there has been a significant reduction in the area of lake, and only the Maloe Lebyazhye has remained. Other lakes of this system dried up. Methods: In 2017, measures were taken to restore the lakes of Bolshoe and Svetloe Lebyazhye: They were deepened to $3 \mathrm{~m}$; the bottom was insulated with bentonitic mats. In October 2017, the lakes were filled with water. For the implementation of water supply, the pressure water conduit was restored to supply water from the nearby Lake Izumrudnoe. The study of the zooplankton community of Lake Maloe Lebyazhye is relevant and necessary to identify changes, occurring after the completion of measures for eco-rehabilitation. Results and Discussion: The article presents the results of studies of the zooplankton community of Lake Maloe Lebyazhye, performed during the growing periods of 2015-2017. In the course of the research, current species composition of zooplankton was revealed, the abundance and biomass were estimated, and the biotic indices were calculated. Conclusions: It is revealed that the zooplankton of the lake is represented by 64 species. The mean values of the abundance and biomass of zooplankton are relatively low and are in the range of values, corresponding to the oligotrophic type of water body.

Key words: Bioindication, eco-rehabilitation, lake, water quality, zooplankton

\section{INTRODUCTION}

$\Delta$ $\mathrm{t}$ present, the problems, associated with the negative human impact on the environment, are acute. Natural objects, located within the boundaries of large cities, including small lakes, are under the particularly strong influence.

Small lakes are of great importance for the conservation of biodiversity of terrestrial and aquatic flora and fauna, within highly transformed urban areas. ${ }^{[1-3]}$ At the same time, they are subjected to a strong impact of external factors, affecting the aquatic ecosystems, and changing the conditions of existence of hydrobionts. ${ }^{[4]}$

Lake Maloe Lebyazhye is located within the specially protected natural area of the city level "Gorlesopark Lebyazhye." Previously, Lake Lebyazhye was the system of lakes. It included the lakes of Maloe, Bolshoe, Svetloe, and Sukhoe Lebyazhye, connected by ducts. At present, only Lake Maloe Lebyazhye exists. One of the reasons for the reduction in the area of lakes is a reduction in the flow of surface runoff, due to the construction of motorway and railway. By origin, Lake Maloe Lebyazhye is interdunal. The lake is snow-fed and atmospheric-fed. It is drainless; it is replenished with water from artesian wells artificially. According to data for 2015, the area of lake is 3.38 hectares; the maximum depth is $2.9 \mathrm{~m}$; its average depth is $0.92 \mathrm{~m}$; and the catchment area of the lake is 73.7 hectares. ${ }^{[5]}$

\section{Address for correspondence:}

Olga Yu. Derevenskaya, Institute of Management, Economics and Finance, Kazan Federal University, 18 Kremlyovskaya Street, Kazan 420008, Russian Federation, Russia. E-mail: oderevenskaya@mail.ru

Received: $22-11-2018$

Revised: 08-12-2018

Accepted: 13-12-2018 
Lake Lebyazhye has a great recreational value; it is a popular resting place. Various festivals and mass events are held there. In 2016, the decision was made to restore the lakes of Bolshoe and Svetloe Lebyazhye within their former boundaries. ${ }^{[6]}$ Lake Bolshoe Lebyazhye and partially Svetloe were deepened to $3 \mathrm{~m}$; the bottom was insulated with bentonitic mats. For the water supply of the lake, the pressure water conduit was restored from Lake Izumrudnoe. In October 2017, the lakes were filled with water.

The purpose of the work is to assess the ecological state of Lake Maloe Lebyazhye by indicators of zooplankton, after the implementation of measures for eco-rehabilitation.

\section{METHODS}

The study of the zooplankton community of Lake Maloe Lebyazhye was carried out during the growing seasons (MaySeptember) of 2015-2017. The samples were taken in the shoal coastal zone, at the distance of 3-5 $\mathrm{m}$ from the shore, at 1 to 2 stations. The samples were collected by straining $50 \mathrm{~L}$ of water through the Apstein net. 44 samples of zooplankton were taken and processed.

Laboratory investigation of samples was performed using conventional hydrobiological techniques..$^{[7]}$ The biomass of zooplankton was calculated with the help of formulas, connecting the length of organisms with their mass. Water quality assessment was carried out using the Pantle-Buck saprobity index in the modification of Sladeček. ${ }^{[8]}$ Species diversity of zooplankton is estimated by the Shannon index (N) (by number and biomass). ${ }^{[9]}$ The Simpson index $(\mathrm{S})^{[10]}$ was calculated to estimate the structure of the community, also in terms of size and biomass.

\section{RESULTS AND DISCUSSION}

Physical and chemical investigations of water in Lake Lebyazhye, carried out in November 2015, showed that the water in Lake Maloe Lebyazhye is odorless, colorless, its medium is neutral. The electrical conductivity of water was $1300 \mathrm{mkSm} / \mathrm{sm}$, and mineralization was in the range from 940 to $1000 \mathrm{mg} / \mathrm{l}$, i.e., it corresponded to weaklymineralized waters. The values are very high, that is due to the replenishment of lake with groundwater from artesian wells.

The content of dissolved oxygen in water is high. The content of ammonium ion exceeded the maximum permissible concentrations. The exceedance of maximum permissible concentrations of copper and iron in water has been noted; however, this may be due to the natural high content of these substances in the waters of the catchment area. The content of nitrates, chlorides, phosphates, petroleum products, and surfactants in water does not exceed the permissible values, and the lake is not contaminated with heavy metals. The index of water impurity corresponds to the class IV, i.e., the water is polluted.

In the community of zooplankton, 64 species have been revealed during 3 years of the research, 34 species of which belong to Rotifera, 20 to Cladocera, and 10 to Copepoda [Figure 1].

Most species are widespread and common. About 70\% (50 species) of all revealed species live in diverse water bodies: $8 \%$ (5 species) live only in fresh waters, $6 \%$ (4 species) - in salty and brackish waters, $3 \%$ - in acid waters, and $1.5 \%$ - in alkaline waters. According to the occurrence of zooplankton, $65 \%$ of the total number of species are worldwide ( 42 species); $8 \%$ (5 species) are widespread everywhere, except Australia; and 4 species of zooplankton are common in the northern and southern latitudes. The remaining 27\% (18 species) are common in various countries and continents. As for the temperature, 9 species of zooplankton are thermophilic, and 1 species is psychrophilic (Polyarthra dolichoptera), the remaining species of zooplankton are able to live in different temperature conditions.

The composition of zooplankton in the period under study was not stable [Table 1], but the total number of species, revealed during the vegetative period, remained approximately the same - 41-44.

During the research period, the dominant complex was formed by the same species, dominant or subdominant. According to the number, the following species were included in the dominant complex the most often: Asplanchna priodonta,

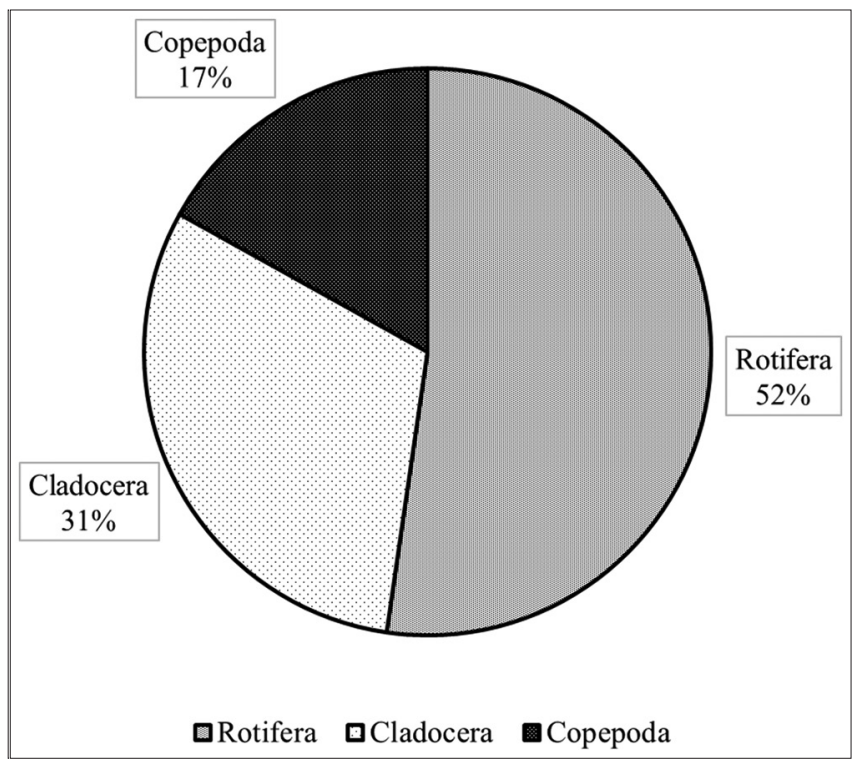

Figure 1: Proportion of the number of zooplankton species (\%) 
Table 1: The occurrence of zooplankton species in 2015-2017

\begin{tabular}{|c|c|c|c|}
\hline Species & 2015 & 2016 & 2017 \\
\hline $\begin{array}{l}\text { Asplanchna priodonta } \\
\text { (Gosse, 1850) }\end{array}$ & + & + & + \\
\hline Asplanchna girodi (Guerne, 1888) & & + & + \\
\hline $\begin{array}{l}\text { Asplanchna sieboldi } \\
\text { (Leydig, 1854) }\end{array}$ & & + & + \\
\hline Anuraeopsis fissa (Gosse, 1851) & + & + & + \\
\hline $\begin{array}{l}\text { Brachionus } \\
\text { quadridentatus (Hermann, } 1783\end{array}$ & + & + & + \\
\hline $\begin{array}{l}\text { Brachionus angularis } \\
\text { (Gosse, 1851) }\end{array}$ & + & + & + \\
\hline $\begin{array}{l}\text { Brachionus calyciflorus } \\
\text { (Pallas, 1766) }\end{array}$ & + & + & + \\
\hline Brachionus diversicornis (Daday) & + & + & + \\
\hline Keratella cochlearis (Gosse, 1851) & + & + & + \\
\hline Keratella quadrata (Muller, 1786) & + & + & + \\
\hline $\begin{array}{l}\text { Platyias quadricornis } \\
\text { (Ehrenberg, 1832) }\end{array}$ & + & + & + \\
\hline $\begin{array}{l}\text { Euchlanis dilatata } \\
\text { (Ehrenberg, 1832) }\end{array}$ & + & + & + \\
\hline Lecane bulla (Gosse, 1851) & + & & \\
\hline $\begin{array}{l}\text { Lecane closterocerca } \\
\text { (Schmarda, 1859) }\end{array}$ & + & & \\
\hline Lecane luna (Müller, 1776) & + & + & + \\
\hline Lecane lunaris (Ehrenberg, 1832) & + & & + \\
\hline $\begin{array}{l}\text { Colurella colurus } \\
\text { (Ehrenberg, 1830) }\end{array}$ & + & & \\
\hline $\begin{array}{l}\text { Polyarthra dolichoptera } \\
\text { (Idelson, 1925) }\end{array}$ & + & + & + \\
\hline $\begin{array}{l}\text { Polyarthra euryptera } \\
\text { (Wierzejski, 1891) }\end{array}$ & + & + & + \\
\hline Polyarthra vulgaris (Carlin, 1943) & + & + & + \\
\hline $\begin{array}{l}\text { Synchaeta stylata } \\
\text { (Wierzejski, } 1893\end{array}$ & + & & \\
\hline $\begin{array}{l}\text { Synchaeta pectinata } \\
\text { (Ehrenberg, } 1832\end{array}$ & & + & + \\
\hline $\begin{array}{l}\text { Trichocerca bidens } \\
\text { (Lucks, 1912) }\end{array}$ & + & & \\
\hline $\begin{array}{l}\text { Trichocerca capucina } \\
\text { (Wierzejski and Zacharias, 1893) }\end{array}$ & + & & \\
\hline $\begin{array}{l}\text { Trichocerca rouselleti } \\
\text { (Voigt, 1902) }\end{array}$ & + & + & + \\
\hline $\begin{array}{l}\text { Trichocerca similis } \\
\text { (Wierzejski, 1893) }\end{array}$ & + & + & \\
\hline $\begin{array}{l}\text { Trichocerca brachyura } \\
\text { (Gosse, 1851) }\end{array}$ & & + & + \\
\hline $\begin{array}{l}\text { Trichocerca elongata } \\
\text { (Gosse, 1886) }\end{array}$ & & + & \\
\hline
\end{tabular}

\section{Table 1: (Continued)}

Species

Trichocerca pusilla

(Lauterborn, 1898)

Trichotria pocillum (Muller, 1776)

Trichotria truncata

(Whitelegge, 1889)

Filinia longiseta (Ehrenberg, 1834)

Hexarthra mira (Hudson, 1871)

Hexarthra fennica

(Levander, 1892)

$\Sigma$ Rotifera

Alona costata (Sars)

Alona rectangula (Sars, 1861

Alonella nana (Baird, 1850)

Chydorus sphaericus

(Mueller, 1785)

Disparalona rostrata (Koch, 1841)

Graptoleberis testudinaria

(Fischer, 1848)

Monospilus dispar (Sars, 1861)

Pleuroxus uncinatus (Baird)

Peracantha truncate (Baird, 1843)

Bosmina longirostris

(Müller, 1776)

Ceriodaphnia laticaudata (Muller)

Daphnia cucullata (Sars, 1862)

Scapholeberis mucronata

(Müller, 1776)

Simocephalus vetulus

(Müller, 1776)

Ilyocryptus agilis (Kurz, 1878)

Ilyocryptus sordidus

(Liévin, 1848)

Macrothrix laticornis (Jurine)

Diaphanosoma

brachyurum (Liévin, 1848)

Diaphanosoma

mongolianum (Ueno, 1938

Sida crystalline (Müller, 1776)

$\sum$ Cladocera

Diacyclops bicuspidatus

(Claus, 1857) (s. lat)

Eucyclops denticulatus

(Graeter, 1903)

Eucyclops speratus

(Lilljeborg, 1901)

Eucyclops macruroides

(Lilljeborg, 1901) $\begin{array}{ccc}2015 & 2016 & 2017 \\ & + & +\end{array}$

$+$
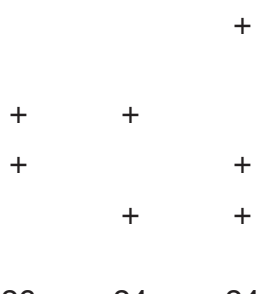

26
24

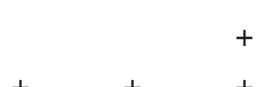

$\begin{array}{lll}+ & + & + \\ & + & \end{array}$

$+\quad+$

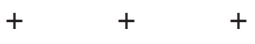

$+$

$+\quad+$

$+$
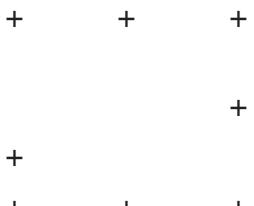

$++$
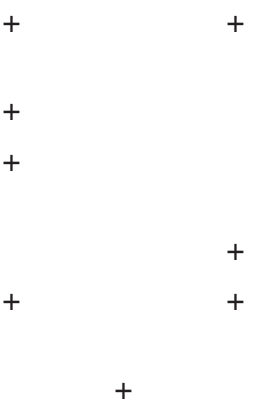

$+\quad+\quad+$

$14 \quad 10 \quad 13$

$+$

$+$ 


\begin{tabular}{|c|c|c|c|}
\hline \multicolumn{4}{|c|}{ Table 1: (Continued) } \\
\hline Species & 2015 & 2016 & 2017 \\
\hline $\begin{array}{l}\text { Eucyclops arcanus } \\
\text { (Alekseev, 1990) }\end{array}$ & & + & \\
\hline Eudiaptomus sp. & & + & \\
\hline $\begin{array}{l}\text { Eucyclops serrulatus } \\
\text { (Fischer, 1851) }\end{array}$ & & + & + \\
\hline $\begin{array}{l}\text { Thermocyclops crassus } \\
\text { (Fischer, 1853) }\end{array}$ & + & + & + \\
\hline $\begin{array}{l}\text { Thermocyclops oithonoides } \\
\text { (Sars G.O., 1863) }\end{array}$ & + & + & + \\
\hline $\begin{array}{l}\text { Mesocyclops leuckarti } \\
\text { (Claus, 1857) }\end{array}$ & + & + & + \\
\hline$\sum$ Copepoda & 4 & 7 & 6 \\
\hline Total & 44 & 41 & 43 \\
\hline
\end{tabular}

Brachionus calyciflorus, Chydorus sphaericus, and Keratella cochlearis. Such species as A. priodonta, B. calyciflorus, Bosmina longirostris, C. sphaericus, M. leucarti, Thermocyclops oithonoides, and Thermocyclops crassus were dominant in biomass.

The average number of zooplankton in 2015 was $42.67 \pm$ 13.147 thousand specimens $/ \mathrm{m}^{3}$. In subsequent years, the abundance decreased and amounted to $22.95 \pm 5.6$ thousand specimens $/ \mathrm{m}^{3}$ and $38.06 \pm 10.13$ thousand specimens $/ \mathrm{m}^{3}$ in 2016 and 2017, respectively. Rotifera species prevailed in number throughout the study period [Figure 2].

The biomass of zooplankton remained low during the period of the research [Figure 3]. The maximum average biomass of zooplankton in the vegetation period was $0.147 \pm 0.053 \mathrm{~g} / \mathrm{m}^{3}$ in 2017. In 2016, the average value of zooplankton biomass was the lowest, $0.059 \pm 0.013 \mathrm{~g} / \mathrm{m}^{3}$, and in $2015-0.111$ $\pm 0.039 \mathrm{~g} / \mathrm{m}^{3}$. According to the classification of Kitaev (1986), the values of biomass relate to the water bodies of $\alpha$-oligotrophic type.

The values of the Shannon index, characterizing the species diversity of zooplankton community in 2015 and 2016 were on the same level, but in 2017 they significantly reduced. The average values of the Shannon index in 2015-2016 corresponded to the oligotrophic type, and in 2017 - to the mesotrophic type. Species diversity of zooplankton is relatively high. The values of the Simpson index changed in the same manner.

The mean values of the Shannon index, calculated from the biomass of zooplankton, varied from 1.9 to 2.6. Low values of this index were due to the prevalence of one of the zooplankton species. Average values of the Simpson index were in the range of $0.5-0.65$, much lower than the values of this index, calculated by the abundance. This is due to the fact that the average biomass of zooplankton in the lake is very

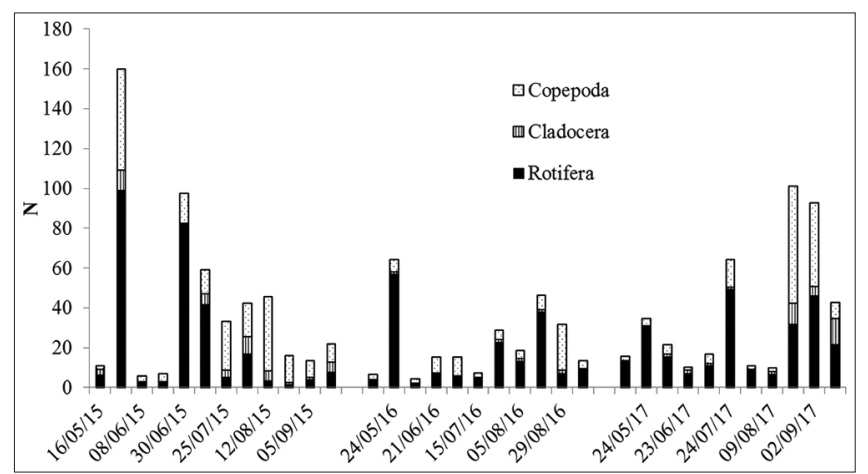

Figure 2: Dynamics of the number of zooplankton in 2015$2017\left(\mathrm{~N}\right.$, thousand specimens $/ \mathrm{m}^{3}$ )

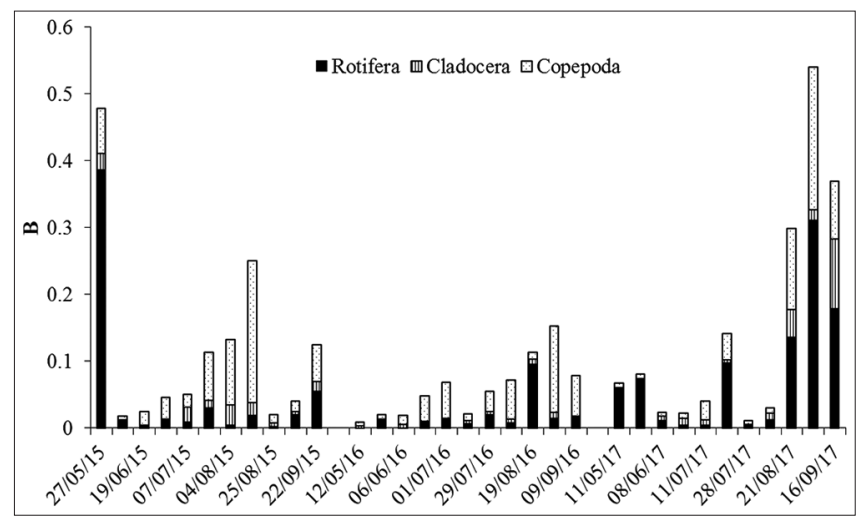

Figure 3: Dynamics of zooplankton biomass $\left(\mathrm{B}, \mathrm{g} / \mathrm{m}^{3}\right)$

low. It is composed mainly of the biomass of rotifers, and the presence of large crustaceans in the sample significantly changes the ratio of zooplankton species biomass and reduces the value of indices.

During the period of study, the values of saprobity index (S) were usually in the range of 1.6-1.71. This corresponds to $\beta$-mesosaprobic zone and indicates moderate contamination of the water body [Figure 4].

The average values of indicators of the zooplankton community of Lake Lebyazhye are presented in Table 2.

Thus, during the study period, the main indices of the zooplankton community have not changed significantly.

\section{SUMMARY}

During 3 years of research in Lake Maloe Lebyazhye, 64 species of zooplankton have been revealed, 34 species of which belong to Rotifera, 20 to Cladocera, and 10 to Copepoda.

In terms of number, the dominant species were the following: A. priodonta, B. calyciflorus, C. phaericus, and $K$. cochlearis. Such species as A. priodonta, B. longirostris, B. calyciflorus, $M$. leuckarti, and $T$. oithonoides were dominant in biomass. 


\begin{tabular}{|c|c|c|c|}
\hline Index & 2015 & 2016 & 2017 \\
\hline Number of species & 49 & 45 & 46 \\
\hline Number of species in sample & 13.3 & 13.7 & 13.1 \\
\hline Abundance of Rotifera (thousand specimens $/ \mathrm{m}^{3}$ ) & $22.7 \pm 9.75$ & $15.3 \pm 5.26$ & $21.98 \pm 4.64$ \\
\hline Abundance of Cladocera (thousand specimens $/ \mathrm{m}^{3}$ ) & $3.71 \pm 0.95$ & $0.91 \pm 0.17$ & $3.28 \pm 1.35$ \\
\hline Abundance of Copepoda (thousand specimens $/ \mathrm{m}^{3}$ ) & $16.26 \pm 4.29$ & $6.73 \pm 1.79$ & $12.8 \pm 5.81$ \\
\hline Total abundance (thousand specimens $/ \mathrm{m}^{3}$ ) & $42.67 \pm 13.15$ & $22.95 \pm 5.61$ & $38.06 \pm 10.13$ \\
\hline Biomass of Rotifera $\left(\mathrm{g} / \mathrm{m}^{3}\right)$ & $0.047 \pm 0.03$ & $0.017 \pm 0.008$ & $0.08 \pm 0.029$ \\
\hline Biomass of Cladocera $\left(\mathrm{g} / \mathrm{m}^{3}\right)$ & $0.013 \pm 0.003$ & $0.004 \pm 0.0008$ & $0.018 \pm 0.009$ \\
\hline Biomass of Copepoda $\left(\mathrm{g} / \mathrm{m}^{3}\right)$ & $0.051 \pm 0.017$ & $0.038 \pm 0.011$ & $0.048 \pm 0.02$ \\
\hline Total biomass $\left(\mathrm{g} / \mathrm{m}^{3}\right)$ & $0.111 \pm 0.039$ & $0.059 \pm 0.013$ & $0.147 \pm 0.053$ \\
\hline Shannon index $(\mathrm{N})$ & $2.65 \pm 0.19$ & $2.65 \pm 0.15$ & $2.4 \pm 0.16$ \\
\hline Shannon index (B) & $2.12 \pm 0.3$ & $2.2 \pm 0.23$ & $1.89 \pm 0.19$ \\
\hline Simpson index (N) & $0.74 \pm 0.05$ & $0.77 \pm 0.03$ & $0.71 \pm 0.036$ \\
\hline Simpson index (B) & $0.5 \pm 0.06$ & $0.65 \pm 0.05$ & $0.59 \pm 0.05$ \\
\hline Saprobity index & $1.6 \pm 0.03$ & $1.61 \pm 0.049$ & $1.7 \pm 0.035$ \\
\hline
\end{tabular}

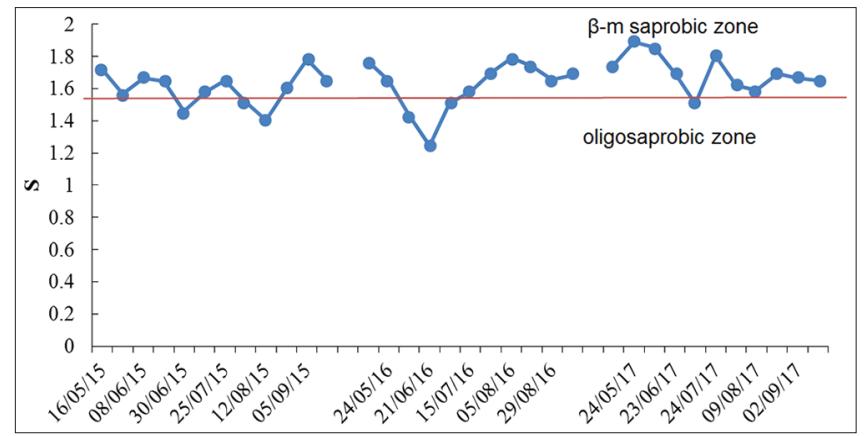

Figure 4: Change in the values of saprobity index (S)

The maximum values of zooplankton abundance in 2015 and 2016 were observed in May, and in 2017 - in August. They were formed mostly by Rotifera species. The maximum values of biomass were most often observed in August and September and were formed by species Rotifera and Copepoda.

The average values of zooplankton abundance varied from $22.95 \pm 5.61$ thousand specimens $/ \mathrm{m}^{3}$ to 42.67 thousand specimens $/ \mathrm{m}^{3}$. The mean values of zooplankton biomass varied from $0.059 \pm 0.013 \mathrm{~g} / \mathrm{m}^{3}$ to $0.147 \pm 0.053 \mathrm{~g} / \mathrm{m}^{3}$. According to the classification of Kitaev (1986), the lake corresponds to the oligotrophic type.

The values of the Shannon index, calculated by number, in 2015 and 2016 corresponded to the oligotrophic type, in 2017 - to mesotrophic. The Shannon index values, calculated by biomass, varied over the years from the values typical for oligotrophic water bodies (in 2015) to eutrophic water bodies (2017). The values of the Simpson index changed in a similar way. According to the value of saprobity index, water in the lake corresponded to $\beta$-mesosaprobic zone, moderately polluted (water quality of class 3 ).

To improve the quality of water in Lake Lebyazhye, a number of measures should be carried out: To develop the coastal zone of the lake; to limit recreational load; to carry out biotechnical activities; to control the water level in the lake; and to monitor the state of the lake.

\section{CONCLUSIONS}

The investigations have shown that the quality of water in Lake Lebyazhye, according to the state of zooplankton community, corresponds to moderately polluted waters. This is due to the anthropogenic impact on the lake, intensive recreational effect, as well as the changes in the type of water, due to the artificial replenishment of the lake by groundwater. This is evidenced by the low species richness of zooplankton, low values of zooplankton abundance and biomass, and low values of biotic indices.

The project for eco-rehabilitation of the Lebyazhye Lakes was implemented in 2017 due to the high value of the lake as a recreational facility. Water from the nearby Lake Izumrudnoe is supplied by pumps to Lake Svetloe Lebyazhye, from which it flows through the ducts into the Bolshoe and Maloe Lebyazhye. The studies, carried out by us, can be used for comparison, and allow to evaluate the effectiveness of the measures, taken for eco-rehabilitation. To obtain reliable information about the state of Lake Lebyazhye, it is necessary to continue the study of the quality of water in the lake, to monitor the state of the environment. 


\section{ACKNOWLEDGMENTS}

The work is performed according to the Russian Government Program of Competitive Growth of Kazan Federal University.

\section{REFERENCES}

1. Cereghino R, Biggs J, Oertli B, Declerck S. The ecology of European ponds: Defining the characteristics of a neglected freshwater habitat. Hydrobiologia 2008;597:19-27.

2. Cereghino R, Ruggiero A, Marty P, Angelibert S. Biodiversity and distribution patterns of freshwater invertebrates in farm ponds of a South Western French agricultural landscape. Hydrobiologia 2008;597:43-51.

3. Pinel-Alloul B, Mimouni E. Are cladoceran diversity and community structure linked to spatial heterogeneity in urban landscapes and pond environments? Hydrobiologia 2013;715:195-212.

4. Mansfield R, Williams A, Hendry K, White K. Drivers of change in a redeveloped urban lake: Long term trends in a simplified system. Fundam Appl Limnol 2104;185:91-105.
5. Derevenskaya O. Zooplankton community of lake Lebyazh'e (Kazan, Russia) under changing conditions. Uch Zap Kazan Univ Seriya Estestven Nauki 2017;159:108-21.

6. Derevenskaya O, Urazaeva N. Dynamics of zooplankton of the Lebyazhye lake in connection with the activities on eco-rehabilitation. Indo Am J Pharm Sci 2107;4:3122-7.

7. Methodical recommendations for the collection and processing of materials for hydrobiological research of freshwater reservoirs. In: Zooplankton and its Products. London: Zoological Institute of the USSR Academy of Sciences-National Research Institute of Lake and River Fisheries; 1982. p. 33.

8. Sladeček V. System of water quality from biological point of view. Egetnisse Limnol 1973;7:218.

9. Shannon CE, Weaver W. The Mathematical Theory of Communication. Urbana: University of Illinois Press; 1949. p. 117.

10. Whittaker RH. Dominance and diversity in land plant communities: Numerical relations of species express the importance of competition in community function and evolution. Science 1965;147:250-60.

Source of Support: Nil. Conflict of Interest: None declared. 